\title{
Effects of nitrogen fertilizer doses on growth and yield of Java lemongrass (Cymbopogon winterianus Jawitt) in Gia Lai province
}

\author{
Tam T. M. Pham ${ }^{1 *}$, Lan P. H. Nguyen ${ }^{1}$, Cuong A. Pham ${ }^{2}$, Hieu Q. Huynh ${ }^{1}$, Hiep D. Dao ${ }^{1}$, \\ Nang D. Nguyen ${ }^{1}$, \& Oanh T. T. Vo ${ }^{1}$ \\ ${ }^{1}$ Faculty of Agronomy, Nong Lam University, Ho Chi Minh City, Vietnam \\ ${ }^{2}$ Binh Dien Fertilizer Joint Stock Company, Ho Chi Minh City, Vietnam
}

\author{
ARTICLE INFO \\ Research Paper \\ Received: October 30, 2018 \\ Revised: November 22, 2018 \\ Accepted: November 29, 2018 \\ Keywords \\ Java lemongrass \\ Lemongrass oil \\ Nitrogen fertilizer \\ ${ }^{*}$ Corresponding author \\ Pham Thi Minh Tam \\ Email: ptmtam@hcmuaf.edu.vn
}

\begin{abstract}
Java lemongrass is commonly cultivated in Vietnam for the food industry and traditional medicine. To achieve high productivity, the application of fertilizer is one of the most traditional farm practices and necessary. A single factorial experiment was carried out in a randomized complete block design to investigate the effect of nitrogen fertilizer doses on growth, leaf and essential oil yields of Java lemongrass. Eight treatments were used in this experiment including $0,15,30,45,60,75$, $90 \mathrm{~kg} \mathrm{~N} /$ ha and applying only 2 tons Komic biofertilizer/ha as control. Fertilizer foundation for treatments 1 - 7 (for $1 \mathrm{ha}$ ) included 2 tonnes of Komix biofertilizer, $60 \mathrm{~kg} \mathrm{P}_{2} \mathrm{O}_{5}$ and $60 \mathrm{~kg} \mathrm{~K} \mathrm{~K}_{2} \mathrm{O}$. The application of $90 \mathrm{~kg} \mathrm{~N} /$ ha significantly improved the growth of Java lemongrass and increased leaf yield (12.02 tons/ha/3 harvest times) as well as resulted in the highest oil yield $(138.1 \mathrm{~kg} / \mathrm{ha} / 3$ harvest times $)$.
\end{abstract}

Cited as: Pham, T. T. M., Nguyen, L. P. H., Pham, C. A., Huynh, H, Q., Dao, H. D., Nguyen, N. D., \& Vo, O. T. T. (2019). Effects of nitrogen fertilizer doses on growth and yield of Java lemongrass (Cymbopogon winterianus Jawitt) in Gia Lai province. The Journal of Agriculture and Development 18(2), 57-64. 


\title{
Ảnh hưởng của liều lượng phân đạm đến sinh trưởng và năng suất sả Java (Cymbopogon winterianus Jawitt) tại tỉnh Gia Lai
}

\author{
Phạm Thị Minh Tâm ${ }^{1 *}$, Nguyễn Phạm Hồng Lan ${ }^{1}$, Phạm Anh Cường ${ }^{2}$, Huỳnh Quốc Hiệu ${ }^{1}$, \\ Đào Duy Hiệp ${ }^{1}$, Nguyễn Duy Năng ${ }^{1}$ \& Võ Thị Thu Oanh ${ }^{1}$ \\ ${ }^{1}$ Khoa Nông Học, Trường Đại Học Nông Lâm TP. Hồ Chí Minh, TP. Hồ Chí Minh \\ ${ }^{2}$ Công Ty Cổ Phần Phân Bón Bình Điền, TP. Hồ Chí Minh
}

\section{THÔNG TIN BÀI BÁO}

\section{Bài báo khoa học}

Ngày nhận: 30/10/2018

Ngày chỉnh sửa: 22/11/2018

Ngày chấp nhận: 29/11/2018

\section{Từ khóa}

Phân đạm

Sả Java

Tinh dầu sả

*Tác giả liên hệ

Phạm Thị Minh Tâm

Email: ptmtam@hcmuaf.edu.vn

\section{TÓM TĂT}

Cây sả Java được trồng phổ biến ở Việt Nam để sử dụng cho công nghiệp và dược liệu. Với sự gia tăng nhu cầu sả nguyên liệu, việc áp dụng phân bón đặc biệt phân đạm là một trong những biện pháp kỹ thuật để tăng sản lượng sả. Một thí nghiệm đơn yếu tố đã được bố trí theo kiểu khối hoàn toàn ngẫu nhiên, 3 lần lặp lại để tìm hiểu ảnh hưởng của liều lượng phân đạm bón đến sinh trưởng của cây, năng suất lá và năng suất tinh dầu của sả Java. Tám nghiệm thức bao gồm $0,5,30,45,60,75,90 \mathrm{~kg} \mathrm{~N} /$ ha và nghiệm thức đối chứng chỉ bón 2 tấn phân hữu cơ vi sinh Komix/ha. Nền phân chung cho các nghiệm thức từ 1 đến 7 (tính cho 1 ha) là 2 tấn phân hữu cơ vi sinh Komix, $60 \mathrm{~kg} \mathrm{P}_{2} \mathrm{O}_{5}$ và $60 \mathrm{~kg} \mathrm{~K} \mathrm{~K}_{2} \mathrm{O}$. Kết quả cho thấy khi bón $90 \mathrm{~kg} \mathrm{~N} / \mathrm{ha}$ cho cây sả sinh trưởng tốt, năng suất lá đạt cao nhất (12,02 tấn/ha/3 đợt) và năng suất tinh dầu đạt cao nhất $(138,1 \mathrm{~kg} / \mathrm{ha} / 3$ đợt).

\section{1. Đặt Vấn Đề}

Cây sả Java (Cymbopogon winterianus Jawitt) được trồng để chiết suất tinh dầu sử dụng trong công nghệ thực phẩm, $\mathrm{y}$ học, sử dụng làm nước hoa và mỹ phẩm (Weiss, 1997; Inouye \& ctv., 2001; Nguyen \& Nguyen, 2012). Trong cuộc sống hiện đại nhu cầu các sản phẩm về tinh dầu, hương liệu và dược liệu có nguồn gốc tự nhiên như sả ngày càng được con người chú trọng và đầu tư khai thác (Le, 2003; Kumar \& ctv., 2007; Kumar \& ctv., 2009). Thị trường nhập khẩu tinh dầu sả ở các quốc gia phát triển như Mỹ, Anh, Pháp, Nhật đang được mở rộng. Việt Nam có rất nhiều thuận lợi về mặt điều kiện tự nhiên cho việc trồng và sản suất các sản phẩm từ cây sả. Gia Lai là một tỉnh thuộc khu vực Tây Nguyên với khí hậu nhiệt đới gió mùa, nhiệt độ trung bình $22-27^{0} \mathrm{C}$, lượng mưa trung bình $1.200-2.500 \mathrm{~mm} /$ năm thích hợp cho cây sả phát triển. Trồng cây sả không yêu cầu kỹ thuật chăm sóc cao lại vừa tận dụng được quỹ đất bỏ hoang, nghèo dinh dưỡng, thiếu nước trong mùa khô cũng như tận dụng được lao động nông nhàn mà vẫn đem lại hiệu quả kinh tế tương đối cao, tạo việc làm và tăng thu nhập cho người lao động. Tuy nhiên, cây sả vẫn chưa được chú trọng chăm sóc, đặc biệt là phân bón cho cây sả để đạt năng suất tinh dầu cao và mang lại hiệu quả kinh tế. Phân bón là một trong những yếu tố chính để tăng năng suất cây trồng, trong đó phân đạm đóng vai trò chủ đạo để tăng năng suất và chất lượng cây trồng (Marschner, 1995; Duong, 2002). Trong kỹ thuật bón phân, việc bón đúng liều lượng để cây sinh trưởng, phát triển tốt cho năng suất cao là rất cần thiết để tránh lãng phí phân bón cũng như đạt hiệu quả cao trong sản xuất. Xác định được liều lượng bón phân đạm thích hợp với từng loại đất, từng vùng sinh thái để sử dụng phân bón hiệu quả là điều cần thiết vì mỗi vùng sinh thái khác nhau đều yêu cầu liều 
lượng bón đạm trên cùng cây trồng khác nhau. Hiện nay vẫn chưa có nhiều nghiên cứu về liều lượng phân đạm bón trên cây sả ở Việt Nam nói chung và ở Gia Lai nói riêng. Xuất phát từ thực tế trên, xác định được liều lượng phân đạm thích hợp cho cây sả Java sinh trưởng tốt, tăng năng suất và đem lại hiệu quả kinh tế cao là cần thiết.

\section{Vật Liệu và Phương Pháp Nghiên Cứu}

Nghiên cứu đã được tiến hành tại đội sản xuất 15, công ty sản xuất Bình Dương, Binh đoàn 15, xã Ia Púch, huyện Chư Prông, tỉnh Gia Lai từ tháng 5 đến tháng 10 năm 2017.

\section{1. Điều kiện thí nghiệm}

Kết quả phân tích mẫu đất Bảng 1 cho thấy đất khu thí nghiệm có $\mathrm{pH}=5,4$ đất chua vừa. Đất khu thí nghiệm thuộc loại đất cát, thành phần hữu cơ nghèo chiếm $1,11 \%$, hàm lượng $\mathrm{N}$ tổng số và $\mathrm{K}_{2} \mathrm{O}$ nghèo, hàm lượng $\mathrm{P}_{2} \mathrm{O}_{5}$ tổng số giàu nhưng lượng $\mathrm{P}_{2} \mathrm{O}_{5}$ dễ tiêu ở mức nghèo. Do cây sả có thể sinh trưởng ở đất nghèo dinh dưỡng nên đất khu thí nghiệm vẫn phù hợp cho cây sả Java sinh trưởng và phát triển.

Trong thời gian làm thí nghiệm, từ tháng 5 đến tháng 10 có lượng mưa lớn, nhiệt độ trung bình $23,69-24,59^{\circ} \mathrm{C}$, độ ẩm cao. Đây là điều kiện thích hợp cho giống sả Java phát triển. Tuy nhiên, tháng 7 lượng mưa quá lớn gây trở ngại cho sự sinh trưởng của cây, cộng với độ ẩm không khí quá cao dễ gây phát sinh bệnh trên vườn sả.

\subsection{Vật liệu nghiên cứu}

Cây sả Java 10 tháng tuổi được trồng từ tháng 8 năm 2016 xen trong vườn cao su với khoảng cách trồng $0,6 \times 0,8 \mathrm{~m}$. Các số liệu kiểm trắng trước thí nghiệm về chiều cao bụi sả $(\mathrm{cm})$, đường kính bụi $(\mathrm{cm})$ và số nhánh/bụi sả đều cho thấy vườn sả trước thí nghiệm đồng đều (Số liệu không đưa vào). Vườn cao su đang trong giai đoạn kiến thiết cơ bản năm thứ 3 , chưa khép tán.

Phân bón: Urê $(46 \%$ N), sử dụng phân đạm Phú Mỹ; Supe lân $\left(16 \% \mathrm{P}_{2} \mathrm{O}_{5}\right)$, sử dụng phân của công ty cổ phần supe phốt phát và hóa chất Lâm Thao; Kali clorua $\left(60 \% \mathrm{~K}_{2} \mathrm{O}\right)$ sử dụng phân của ISRAEL nhập khẩu bởi Công ty TNHH Phú Thịnh; Phân hữu cơ vi sinh Quế Lâm của Công ty Cổ phần Quế Lâm, thành phần: $\mathrm{HC} 15 \%$, độ ẩm $30 \%$, VSV có ích $3 \times 10^{5} \mathrm{CFU} / \mathrm{g}$, humic $3 \%$. 


\subsection{Bố trí thí nghiệm}

Thí nghiệm một yếu tố được bố trí theo kiểu khối hoàn toàn ngẫu nhiên, 3 lần lặp lại, 8 nghiệm thức bao gồm $0,15,30,45,60,75,90 \mathrm{~kg} \mathrm{~N} /$ ha và bón 2 tấn phân hữu cơ vi sinh Komix (bón theo binh đoàn 15 - đối chứng). Lượng phân nền 2 tấn phân Komix +60 kg $\mathrm{P}_{2} \mathrm{O}_{5} / \mathrm{ha}+60 \mathrm{~kg} \mathrm{~K}{ }_{2} \mathrm{O} / \mathrm{ha}$ cho các nghiệm thức từ 1 đến 7 . Diện tích mỗi ô là $32 \mathrm{~m}^{2}$. Tổng diện tích khu thí nghiệm là 768 $\mathrm{m}^{2}$. Mật độ trồng là 12.500 cây/ha.

\subsection{Phương pháp bón phân}

Nền phân chung cho thí nghiệm (tính cho 1 ha): 2 tấn phân hữu cơ vi sinh Komix, 60 kg $\mathrm{P}_{2} \mathrm{O}_{5}, 60$ $\mathrm{kg} \mathrm{K} \mathrm{K}_{2} \mathrm{O}$.

Bón thúc lần 1 (tháng 5/2017) đầu mùa mưa: Hai tấn phân hữu cơ vi sinh Komix + toàn bộ phân lân $+2 / 5 \mathrm{~N}+2 / 5 \mathrm{~K}_{2} \mathrm{O}$.

Lần 2: Sau khi bón lần 1 từ $45-55$ ngày (sau khi thu hoạch lá sả đợt 1), bón $2 / 5 \mathrm{~N}+2 / 5 \mathrm{~K}_{2} \mathrm{O}$.

Lần 3: Sau khi bón lần 2 từ 45 - 55 ngày (sau khi thu hoạch lá sả đợt 2): $1 / 5 \mathrm{~N}+1 / 5 \mathrm{~K}_{2} \mathrm{O}$. Bón theo binh đoàn 15: Bón thúc 2 tấn phân hữu cơ vi sinh Komix vào đầu mùa mưa và không bón bất kì một loại phân vô cơ nào.

Cách bón: Rải phân dọc theo hàng sả sau đó lấp đất lại.

\subsection{Các chỉ tiêu và phương pháp theo dõi}

Chọn 8 bụi trên ô cơ sở theo đường chéo góc. Theo dõi 2 lần khi thu hoạch ở mỗi đợt. Mỗi đợt thu hoạch cách nhau 45 ngày. Thí nghiệm có 3 đợt thu hoạch. Chiều cao bụi $(\mathrm{cm})$ đo được từ gốc đến vuốt lá cao nhất. Chiều dài lá $(\mathrm{cm})$ được đo từ cổ lá đến chóp lá của lá cao nhất thây rõ cổ lá. Trọng lượng lá trung bình 1 bụi $(\mathrm{g})$ là trung bình của tổng trọng lượng lá 8 bụi; Năng suất lá thực thu (tấn/ha/đợt thu hoạch): Khối lượng lá thu hoạch được trên 1 ô cơ sở và qui về 1 ha. Hàm lượng tinh dầu $(\%)$ được chiết xuất bằng phương pháp lôi cuốn hơi nước. Năng suất tinh dầu thực thu $(\mathrm{kg} / \mathrm{ha} /$ đợt thu hoạch $)=$ (hàm lượng tinh dầu $(\%$ FW) $\times$ năng suất lá tươi thực thu (tấn/ha/đợt thu hoạch) $\times 1.000) / 100$.

\subsection{Phương pháp xử lý số liệu}

Số liệu thu thập từ thí nghiệm được tổng hợp và xử lý bằng phần mềm Excel. Chỉ tiêu được xử lý ANOVA và phân hạng LSD $(\alpha=0,05)$ bằng phần mềm thống kê SAS.

\section{Kết Quả và Thảo Luận}

\section{1. Ảnh hưởng của liều lượng phân đạm đến sinh trưởng của cây sả}

Kết quả số liệu ở Bảng 2 cho thấy chiều cao bụi sả khác biệt không có ý nghĩa thống kê khi bón tăng liều lượng phân đạm từ $0-90 \mathrm{~kg} / \mathrm{ha}$ ở đợt thu hoạch 1, dao động từ $97-111,6 \mathrm{~cm}$. Kết quả này có thể do mới bón phân đạm nên đạm chưa tác động nhiều đến cây sả. Ở đợt thu hoạch 2 và 3 , chiều cao bụi sả đạt cao nhất khi cây sả được bón $90 \mathrm{~kg} \mathrm{~N} / \mathrm{ha}$, lần lượt là 127,6 cm/bụi và $125,9 \mathrm{~cm} /$ bụi, khác biệt rất có ý nghĩa so với chiều cao bụi ở cây không bón phân đạm, lần lượt là $109,9 \mathrm{~cm} /$ bụi và $100,7 \mathrm{~cm} /$ bụi. Kết quả này tương tự kết quả của Gubta \& ctv. (1978) và Gajbhiye \& ctv. (2013) khi cho rằng bón tăng lượng phân từ 60:30:30 kg NPK/ha đến 90:45:45 $\mathrm{kg} \mathrm{NPK} /$ ha và 120:60:60 kg NPK/ha đã cải thiện chiều cao bụi sả. Abdalla (2000) cũng cho thấy bón tăng liều lượng phân đạm cho sả Cymbopogon proximus làm tăng chiều cao bụi sả và tốc độ sinh trưởng của sả tăng. Mặc dù không được bón phân đạm nhưng cây được bón 2 tấn phân hữu cơ vi $\sinh +60 \mathrm{Kg} \mathrm{P}_{2} \mathrm{O}_{5}+60 \mathrm{Kg} \mathrm{K} 2 \mathrm{O}$ vẫn cho chiều cao bụi cao hơn là 109,9 cm/bụi (ở đợt thu hoạch 2), khác biệt rất có ý nghĩa so với chiều cao bụi ở cây đối chứng không được bón bất kỳ loại phân vô cơ nào.

Bảng 2. Ảnh hưởng của liều lượng phân đạm đến chiều cao bụi sả

\begin{tabular}{cccc}
\hline $\begin{array}{c}\text { Lượng N bón } \\
(\mathrm{kg} / \mathrm{ha})\end{array}$ & \multicolumn{3}{c}{ Chiều cao bụi sả $(\mathrm{cm})$} \\
\cline { 2 - 4 } & Đợt 1 & Đợt 2 & Đợt 3 \\
\hline 0 & 106,3 & $109,9^{\mathrm{c}}$ & $101,7^{\mathrm{d}}$ \\
15 & 111,6 & $113,4^{\mathrm{bc}}$ & $115,0^{\mathrm{b}}$ \\
30 & 101,3 & $112,1^{\mathrm{c}}$ & $113,2^{\mathrm{bc}}$ \\
45 & 97,0 & $112,6^{\mathrm{c}}$ & $111,7^{\mathrm{bcd}}$ \\
60 & 107,6 & $117,0^{\mathrm{bc}}$ & $114,8^{\mathrm{b}}$ \\
75 & 101,3 & $121,3^{\mathrm{ab}}$ & $121,0^{\mathrm{ab}}$ \\
90 & 106,3 & $127,6^{\mathrm{a}}$ & $125,9^{\mathrm{a}}$ \\
2 tấn Komix & 103,7 & $100,1^{\mathrm{d}}$ & $103,8^{\mathrm{cd}}$ \\
$(\mathrm{D} / \mathrm{C})$ & & & \\
\hline $\mathrm{CV}(\%)$ & 7,2 & 4,0 & 5,0 \\
\hline $\mathrm{F}$ & $1,1^{\mathrm{ns}}$ & $9,4^{* *}$ & $6,1^{* *}$ \\
\hline
\end{tabular}

a-d Trên cùng một cột các trị số có cùng ký tự đi kèm khác biệt không có ý nghĩa thống kê. **: khác biệt rất có ý nghĩa thống kê $(\alpha \leq 0,01)$; ns: khác biệt không có ý nghĩa thống kê. 
Tương tự như chiều cao bụi sả, chiều dài lá sả khác biệt không có ý nghĩa thống kê khi bón tăng liều lượng phân đạm từ $0-90 \mathrm{~kg} / \mathrm{ha}$ ở đợt thu hoạch 1 , dao động từ 79,0 - 87,1 cm. Kết quả này có thể do mới bón phân đạm nên đạm chưa tác động nhiều đến cây sả. Ở đợt thu hoạch 2 và 3 , chiều dài lá sả cũng dài nhất khi cây sả được bón $90 \mathrm{~kg} \mathrm{~N} / \mathrm{ha}$, lần lượt là $89,2 \mathrm{~cm}$ và $91,9 \mathrm{~cm}$, khác biệt rất có ý nghĩa so với chiều dài lá sả ở cây không bón phân đạm. Mặc dù không được bón đạm nhưng cây được bón 2 tấn phân hữu cơ vi sinh Komix $+60 \mathrm{~kg} \mathrm{P} \mathrm{P}_{2} \mathrm{O}_{5}+60 \mathrm{~kg} \mathrm{~K} \mathrm{~K}_{2} \mathrm{O}$ vẫn cho chiều dài lá sả dài hơn là $79,4 \mathrm{~cm}$ (ở đợt thu hoạch 2), khác biệt rất có ý nghĩa so với chiều cao bụi ở cây đối chứng không được bón bất kỳ loại phân vô cơ nào là $70,9 \mathrm{~cm}$. Tuy nhiên ở đợt thu hoạch thứ 3 do lúc này phân hữu cơ đã có tác dụng nên chiều dài lá sả của cây đối chứng chỉ bón phân 2 tấn phân hữu cơ vi sinh Komix cũng đã tương đương và khác biệt không có ý nghĩa so với chiều dài lá sả ở cây không bón phân đạm (Bảng 3).

Bảng 3. Ảnh hưởng của liều lượng phân đạm đến chiều dài lá sả

\begin{tabular}{cccc}
\hline \multirow{2}{*}{$\begin{array}{c}\text { Lượng N bón } \\
(\mathrm{kg} / \mathrm{ha})\end{array}$} & \multicolumn{3}{c}{ Chiều dài lá sả $(\mathrm{cm})$} \\
\cline { 2 - 4 } & Đợt 1 & Đợt 2 & Đợt 3 \\
\hline 0 & 82,6 & $79,4^{\mathrm{b}}$ & $74,1^{\mathrm{c}}$ \\
15 & 83,0 & $79,9^{\mathrm{b}}$ & $83,0^{\mathrm{abc}}$ \\
30 & 79,0 & $78,4^{\mathrm{bc}}$ & $82,2^{\mathrm{bc}}$ \\
45 & 77,3 & $76,9^{\mathrm{bc}}$ & $80,1^{\mathrm{bc}}$ \\
60 & 81,5 & $81,7^{\mathrm{ab}}$ & $82,3^{\mathrm{bc}}$ \\
75 & 78,5 & $84,0^{\mathrm{ab}}$ & $87,3^{\mathrm{ab}}$ \\
90 & 87,1 & $89,2^{\mathrm{a}}$ & $91,9^{\mathrm{a}}$ \\
2 tấn Komix (Đ/C) & 79,1 & $70,9^{\mathrm{c}}$ & $75,5^{\mathrm{c}}$ \\
\hline CV $(\%)$ & 6,0 & 5,3 & 6,0 \\
\hline $\mathrm{F}$ & $1,3^{\mathrm{ns}}$ & $4,8^{* *}$ & $4,2^{*}$ \\
\hline
\end{tabular}

${ }^{a-c}$ Trên cùng một cột các trị số có cùng ký tự đi kèm khác biệt không có ý nghĩa thống kê. *: khác biệt có ý nghĩa thống kê $(\alpha \leq 0,05) ; *^{*}$ : khác biệt rất có ý nghĩa thống kê $(\alpha \leq 0,01)$; ns: khác biệt không có ý nghĩa thống kê.

\section{2. Ảnh hưởng của liều lượng phân đạm đến khối lượng lá 1 bụi và năng suất lá sả thực thu}

Kết quả ở Bảng 4 cho thấy phân đạm đã có tác dụng đến khối lượng lá 1 bụi của cây sả, bón phân đạm ở liều lượng $90 \mathrm{~kg} \mathrm{~N} /$ ha cho cây sả có khối lượng lá 1 bụi cao nhất ở cả 3 đợt thu hoạch lần lượt là 306,7 g (đợt 1), 343,3 g (đợt 2) và $340,5 \mathrm{~g}$ (đợt 3 ), khác biệt rất có ý nghĩa so với cây sả không được bón phân đạm hay không bón bất kỳ 1 loại phân vô cơ nào như công thức của binh đoàn 15 .

Bảng 4. Ảnh hưởng của liều lượng phân đạm đến khối lượng lá 1 bụi

\begin{tabular}{|c|c|c|c|}
\hline \multirow{2}{*}{$\begin{array}{l}\text { Lượng N bón } \\
\qquad(\mathrm{kg} / \mathrm{ha})\end{array}$} & \multicolumn{3}{|c|}{$\begin{array}{c}\text { Trọng lượng lá } 1 \text { bụi đợt } \\
\text { (g/bụi) }\end{array}$} \\
\hline & Đợt 1 & Đợt 2 & Đợt 3 \\
\hline 0 & $166,7^{\mathrm{b}}$ & $156,7^{\mathrm{b}}$ & $196,8^{\mathrm{d}}$ \\
\hline 15 & $170,0^{\mathrm{b}}$ & $222,5^{\mathrm{ab}}$ & $270,1^{\mathrm{bc}}$ \\
\hline 30 & $214,2^{\mathrm{b}}$ & $217,5^{\mathrm{ab}}$ & $273,6^{\mathrm{bc}}$ \\
\hline 45 & $205,0^{\mathrm{b}}$ & $242,5^{\mathrm{ab}}$ & $215,2^{\text {cd }}$ \\
\hline 60 & $205,8^{\mathrm{b}}$ & $236,7^{\mathrm{ab}}$ & $290,1^{\mathrm{ab}}$ \\
\hline 75 & $245,8^{\mathrm{ab}}$ & $246,7^{\mathrm{ab}}$ & $293,6^{\mathrm{ab}}$ \\
\hline 90 & $306,7^{\mathrm{a}}$ & $343,3^{\mathrm{a}}$ & $340,5^{\mathrm{a}}$ \\
\hline $\begin{array}{c}2 \text { tấn Komix } \\
(\mathrm{D} / \mathrm{C})\end{array}$ & $165,0^{\mathrm{b}}$ & $128,3^{\mathrm{b}}$ & $230,1^{\text {bcd }}$ \\
\hline CV $(\%)$ & 16,2 & 25,4 & 13,1 \\
\hline $\mathrm{F}$ & $5,8^{* *}$ & $3,8^{*}$ & $5,6^{* *}$ \\
\hline
\end{tabular}

a-d TTrên cùng một cột các trị số có cùng ký tự đi kèm khác biệt không có ý nghĩa thống kê. * : khác biệt có ý nghĩa thống kê $(\alpha \leq 0,05)$; **: khác biệt rất có ý nghĩa thống kê $(\alpha \leq 0,01)$; ns: khác biệt không có ý nghĩa thống kê.

Theo Wany \& ctv. (2013), năng suất lá sả năm thứ nhất dao động từ 4,2-5,6 tâ̂n/ha/2 đợt thu hoạch. Theo Marschner (1995) và Duong (2002), phân đạm đóng vai trò quan trọng để tăng năng suất cây trồng. Kết quả Bảng 5 cho thấy khi tăng lượng đạm bón trong khoảng từ $0-90 \mathrm{~kg} \mathrm{~N} / \mathrm{ha}$ thì năng suất lá sả thực thu càng tăng. Ở cả 3 đợt thu hoạch, bón $90 \mathrm{~kg} \mathrm{~N} /$ ha cho cây sả đạt năng suất lá thực thu cao nhất (3,68 tấn/ha/đợt 1; 4,11 tấn/ha/dợt 2 và 4,23 tấn/ha/đợt 3 ) và tổng năng suất lá sả thực thu của 3 dợt cũng cao nhất đạt 12,02 tấn/ha/3 đợt, khác biệt rất có ý nghĩa thống kê so với cây đối chứng không bón đạm không bón bất kỳ 1 loại phân vô cơ nào như công thức của binh đoàn 15 . Kết quả này tương tự như kết quả của nhiều nghiên cứu đã công bố khi cho rằng năng suất lá sả tăng theo đường thẳng khi tăng lượng đạm bón (Rao \& ctv., 1985; Singh, 2001; Singh \& ctv., 2009) hoặc lượng bón thích hợp nhất cho sả là $100 \mathrm{~kg} \mathrm{~N} /$ ha (Singh \& ctv., 1997; Rao \& ctv., 1998). Nguyen \& Bui (2015) cũng cho thấy năng suất lá sả đạt cao nhất tương đương với $181 \%$ khi cây được bón urê ở liều lượng $90 \mathrm{~kg} \mathrm{~N} /$ ha so với cây đối chứng không bón đạm. Gajbhiye \& ctv. (2013) cũng nhận được kết quả tương tự khi kết luận rằng bón 120:60:60 kg NPK/ha cho cây sả đã làm tăng năng suất lá sả. Tuy nhiên, cây sả được bón từ $30-75 \mathrm{~kg} \mathrm{~N} / \mathrm{ha}$ cho năng suất lá sả thực thu khác biệt không có 
Bảng 5. Ảnh hưởng của liều lượng phân đạm đến năng suất lá sả thực thu

\begin{tabular}{ccccc}
\hline \multirow{2}{*}{ Lượng N bón (kg/ha) } & \multicolumn{4}{c}{ Năng suất lá thực thu (tấn/ha) } \\
\cline { 2 - 5 } & Đợt 1 & Đợt 2 & Đợt 3 & Tổng 3 đợt \\
\hline 0 & $1,91^{\mathrm{c}}$ & $1,83^{\mathrm{d}}$ & $2,37^{\mathrm{c}}$ & $6,11^{\text {ef }}$ \\
15 & $2,04^{\mathrm{c}}$ & $2,35^{\mathrm{c}}$ & $3,02^{\mathrm{bc}}$ & $7,41^{\mathrm{de}}$ \\
30 & $2,51^{\mathrm{bc}}$ & $2,63^{\mathrm{bc}}$ & $3,33^{\mathrm{abc}}$ & $8,47^{\mathrm{bcd}}$ \\
45 & $2,19^{\mathrm{c}}$ & $2,94^{\mathrm{b}}$ & $2,60^{\mathrm{bc}}$ & $7,73^{\mathrm{cd}}$ \\
60 & $2,48^{\mathrm{bc}}$ & $2,86^{\mathrm{bc}}$ & $3,56^{\mathrm{ab}}$ & $8,90^{\mathrm{bc}}$ \\
75 & $2,95^{\mathrm{b}}$ & $2,94^{\mathrm{ab}}$ & $3,60^{\mathrm{ab}}$ & $9,49^{\mathrm{b}}$ \\
90 & $3,68^{\mathrm{a}}$ & $4,11^{\mathrm{a}}$ & $4,23^{\mathrm{a}}$ & $12,02^{\mathrm{a}}$ \\
\hline tấn Komix (Đ/C) & $1,95^{\mathrm{c}}$ & $1,53^{\mathrm{d}}$ & $2,55^{\mathrm{bc}}$ & $6,03^{\mathrm{f}}$ \\
\hline $\mathrm{CV}(\%)$ & 9,89 & 8,01 & 18,79 & 9,06 \\
\hline F & $18,39^{* *}$ & $41,74^{* *}$ & $3,49^{*}$ & $20,44^{* *}$ \\
\hline
\end{tabular}

a-f Trên cùng môt côt các tri số có cùng ký tư đi kèm khác biệt không có ý nghĩa thống kê. *: khác biệt có ý nghĩa thống kê $(\alpha \leq 0,05)$; **: khác biệt rất có ý nghĩa thống kê ( $\alpha \leq 0,01)$; ns: khác biệt không có ý nghĩa thống kê.

ý nghĩa thống kê ở cả 3 đợt thu hoạch. Tương tự, bón 60:30:30 $\mathrm{kg} \mathrm{NPK} /$ ha và 90:45:45 $\mathrm{kg} \mathrm{NPK} / \mathrm{ha}$ cho cây sả không làm năng suất sả tăng khác biệt không có ý nghĩa thống kê (Gajbhiye \& ctv., 2013). Zheljazkov \& ctv. (2011) cũng kết luận năng suất sả đạt cao nhất khi bón $160 \mathrm{~kg} \mathrm{~N} /$ ha nhưng năng suất sả khác biệt không có ý nghĩa thống kê so với năng suất của cây sả được bón 80 $\mathrm{kg} \mathrm{N} / \mathrm{ha}$.

\section{3. Ảnh hưởng của liều lượng phân đạm đến hàm lượng tinh dầu sả và năng suất tinh dầu sả}

Toàn bộ cây sả đều chứa tinh dầu nhưng lá chứa tinh dầu nhiều nhất. Kết quả ở Bảng 6 cho thấy hàm lượng tinh dầu sả chỉ bị tác động bởi việc bón đạm ở đợt thu hoạch 3. Bón từ $15-75$ $\mathrm{kg} \mathrm{N} /$ ha đã cải thiện hàm lượng tinh dầu trong lá sả, làm cho hàm lượng tinh dầu sả trong cây cao hơn và khác biệt rất có ý nghĩa thống kê so với cây được bón $90 \mathrm{~kg} \mathrm{~N} /$ ha hay cây đối chứng không bón đạm hay không bón bất kỳ một loại phân vô cơ nào. Kết quả này tương tự với kết quả của Gajbhiye \& ctv. (2013) khi cho rằng bón 60:30:30 $\mathrm{kg} \mathrm{NPK} /$ ha và 90:45:45 kg NPK/ha đã cải thiện chất lượng tinh dầu trên cây sả. Hàm lượng tinh dầu sả ở đợt thu hoạch 1 và 2 đều cao hơn đợt thu hoạch 3. Kết quả này có thể được giải thích là hàm lượng tinh dầu trong lá tươi thay đổi theo mùa vụ. Vào mùa khô là $0,6-1,2 \%$, mùa mưa là $0,5-0,6 \%$, thậm chí có thể đạt đến $1,8 \%$ vào mùa khô và $0,75 \%$ vào mùa mưa (Nguyen \& Nguyen, 2012; VMMU, 2013). Wany \& ctv. (2013) cũng cho rằng hàm lượng tinh dầu sả Java trung bình trong lá tươi vào khoảng $1 \%$. Trong thí nghiệm, hàm lượng tinh dầu sả Java dao động từ 0,96 $1,40 \%$ là khá cao so với các kết quả nghiên cứu trên. Đối với nghiên cứu này, đợt thu hoạch 3 đã ở vào giữa mùa mưa nên có thể hàm lượng tinh dầu sả trong cây thấp hơn đợt 1 và đợt 2 là thời gian bắt đầu vào mùa mưa. Blank \& ctv. (2007) cho rằng hàm lượng tinh dầu thu được ở lá sả khô sẽ cao hơn lá tươi. Ahmed (2000) kết luận hàm lượng tinh dầu trong cây thay đổi theo mùa trong năm.

Bảng 6. Ảnh hưởng của liều lượng phân đạm đến hàm lượng tinh dầu

\begin{tabular}{cccc}
\hline \multirow{2}{*}{$\begin{array}{c}\text { Lượng N bón } \\
(\mathrm{kg} / \mathrm{ha})\end{array}$} & \multicolumn{3}{c}{ Hàm lượng tinh dầu sả } \\
\cline { 2 - 4 }$(\%)$ \\
\hline 0 & Đợt 1 & Đợt 2 & Đợt 3 \\
\hline 15 & 1,40 & 1,17 & $0,96^{\mathrm{b}}$ \\
30 & 1,40 & 1,11 & $1,11^{\mathrm{ab}}$ \\
45 & 1,40 & 1,17 & $1,08^{\mathrm{ab}}$ \\
60 & 1,34 & 1,20 & $1,08^{\mathrm{ab}}$ \\
75 & 1,34 & 1,14 & $1,14^{\mathrm{ab}}$ \\
90 & 1,31 & 1,11 & $1,17^{\mathrm{a}}$ \\
2 tấn Komix (Đ/C) & 1,40 & 1,11 & $0,96^{\mathrm{b}}$ \\
\hline $\mathrm{CV}(\%)$ & 1,40 & 1,08 & $0,96^{\mathrm{b}}$ \\
\hline $\mathrm{F}$ & $0,19^{\mathrm{ns}}$ & 5,63 & 6,29 \\
\hline
\end{tabular}

a-b Trên cùng một cột các trị số có cùng ký tự đi kèm khác biệt không có ý nghĩa thống kê.**: khác biệt rất có ý nghĩa thống kê $(\alpha \leq 0,01)$; ns: khác biệt không có ý nghĩa thống kê.

Kết quả ở Bảng 7 cho thấy khi tăng lượng đạm bón cho cây sả trong khoảng từ $0-90 \mathrm{~kg} \mathrm{~N} / \mathrm{ha}$ thì năng suất tinh dầu sả thực thu càng tăng. Kết quả này tương tự như kết quả của Singh \& 


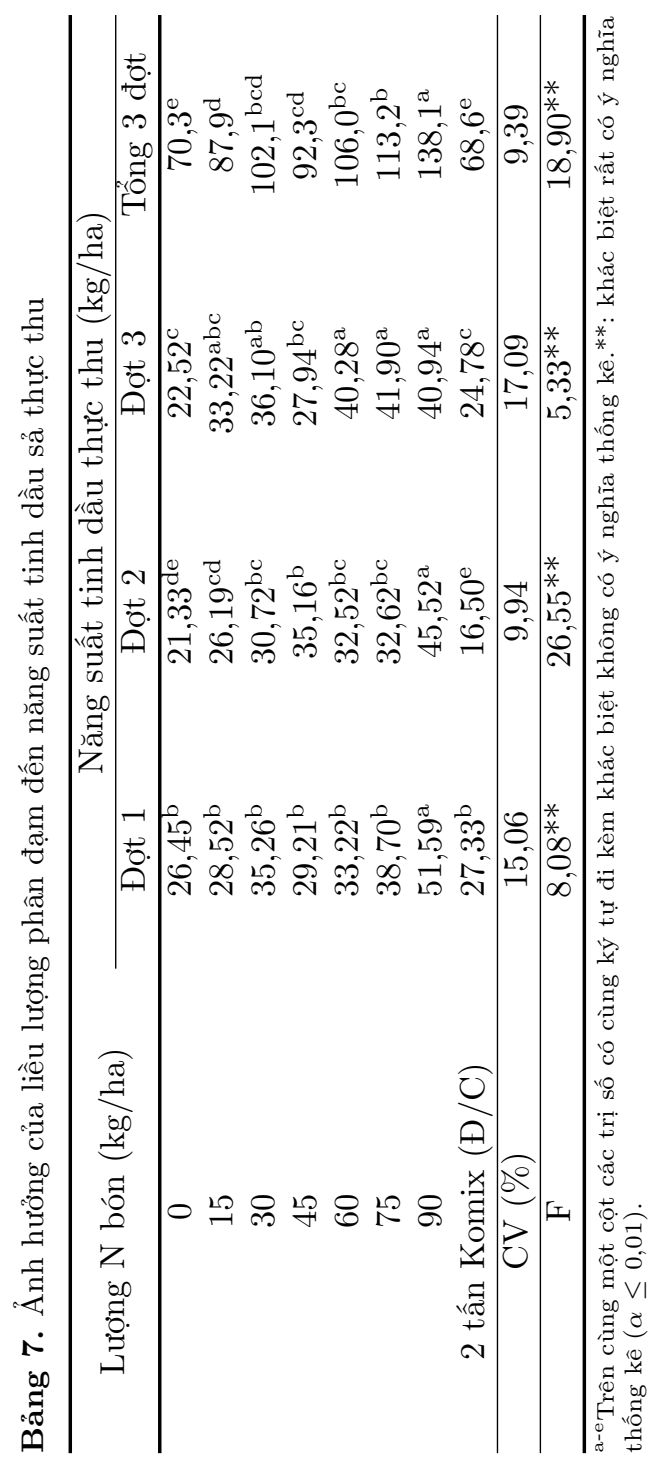

ctv. (1996), Singh \& ctv. (1998), Singh \& Sharma (2001) khi cho rằng bón đạm làm tăng năng suất lá sả, do đó làm tăng năng suất tinh dầu sả. Ở cả 3 đợt thu hoạch, cây sả được bón $90 \mathrm{~kg}$ $\mathrm{N} /$ ha cho năng suất tinh dầu thực thu cao nhất (51,59 kg/ha/đợt $1 ; 45,52 \mathrm{~kg} /$ ha/đợt 2 và 40,94 $\mathrm{kg} / \mathrm{ha} /$ đợt 3) và tổng năng suất tinh dầu sả thực thu của 3 đợt cũng cao nhất đạt $138,1 \mathrm{~kg} / \mathrm{ha} / 3$ đợt, khác biệt rất có ý nghĩa thống kê so với cây không được bón đạm hay cây đối chứng không được bón bất kỳ 1 loại phân vô cơ nào (Công thức của binh đoàn 15). Theo Wany \& ctv. (2013), năng suất tinh dầu sả trung bình năm thứ nhất là $28-42 \mathrm{~kg} / \mathrm{ha} / 2$ đợt thu hoạch. Kết quả của thí nghiệm này cao hơn so với kết quả của Wany \& ctv. (2013).

\section{Kết Luận}

Bón $90 \mathrm{~kg} \mathrm{~N} /$ ha cho cây sả sinh trưởng tốt về chiều cao bụi sả $(127,6 \mathrm{~cm} /$ bụi và $125,9 \mathrm{~cm} /$ bụi lần lượt ở đợt thu hoạch 2 và 3 ), chiều dài lá sả (89,2 cm và $91,9 \mathrm{~cm}$ lần lượt ở đợt thu hoạch 2 và 3$)$, năng suất lá đạt cao nhất (12,02 tấn/ha/3 đợt) và năng suất tinh dầu đạt cao nhất $(138,1$ $\mathrm{kg} / \mathrm{ha} / 3$ đợt).

\section{Lời Cảm Ơn}

Chân thành cảm ơn Trường Đại học Nông Lâm TP.HCM đã tài trợ kinh phí cho nghiên cứu và Công ty sản xuất Bình Dương, Binh đoàn 15 đã tạo điều kiện cho nhóm nghiên cứu được triển khai thí nghiệm trên vườn sả của Đội sản xuất 15 của Công ty ở xã Ia Púch, huyện Chư Prông, tỉnh Gia Lai.

\section{Tài Liệu Tham Khảo (References)}

Abdalla, A. I. (2000). Effect of Nitrogen and organic fertilization on the leaves yield and oil content of camel's Hay plant 'Mahareb'. (Unpublished master's thesis). University of Khartoum, Sambat, Sudan.

Ahmed, M. A. A. (2000). Effect of season, plant age and cultural factor on herbage yield and alkaloid content of two Catharanthus roseus cultivars. (Unpublished doctoral dissertation). University of Khartoum, Sambat, Sudan.

Blank, A. F., Costa, A. G., Arrigoni-Blank, M. de F., Cavalcanti, S. C. H., Alves, P. B., Innecco, R., Ehlert, P. A. D., \& Sousa, I. F. de. (2007). Influence of season, harvest time and drying on Java citronella (Cymbopogon winterianus Jowitt) volatile oil. Revista Brasileira de Farmacognosia 17(4), 557-564. 
Duong, D. H. (2002). Handbook of fertilizer. Ha Noi, Vietnam: Ha Noi Publishing House.

Gajbhiye, B. R., Momin, Y.D., \& Puri, A. N. (2013). Effect of FYM and NPK fertilization on growth and quality parameters of Lemongrass (Cymbopogon flexuosus). Agricultural Science Research Journal 3(4),115120.

Gubta, R., Maheswari, M. L., \& Sing, R. R. (1978). Effect of N.P.K. fertilizer on growth and essential oil content of Palmarosa grass (C. martini molia). Indian perfume 22(2), 79-87.

Inouye, S., Takizawa, T., \& Yamaguchi, H. (2001). Antibacterial activity of essential oils and their major constituents against respiratory tract pathogens by gaseous contact. Journal of Antimicrobial Chemotherapy $47,565-573$.

Kumar, A., Shukla, R., Singh, P., \& Dubey, N. K. (2009). Biodeterioration of some herbal raw materials by storage fungi and aflatoxin and assessment of Cymbopogon flexuosus essential oil and its components as antifungal. International Biodeterioration \& Biodegradation 63(6), 712-716.

Kumar, R., Dubey, N. K., Tiwari, O. P., Tripathi, Y. B., \& Sinha, K. K. (2007). Evaluation of some essential oils as botanical fungitoxicants for the protection of stored food commodities from fungal infestation. Journal of the Science of Food and Agriculture 87(9), 1737-1742.

Le, T. N. (2003). Essential oils. Ho Chi Minh City, Vietnam: Vietnam National University.

Marschner, H. (1995). Mineral nutrition of higher plants ( $2^{\text {nd }}$ ed.). London, England: Academic Press.

Nguyen, H. T., \& Nguyen, Q. K. (2012). Module of lemongrass cultivation-lecture note. Ha Noi, Vietnam: Ministry of Agriculture and Rural Development.

Nguyen, K. T. D., \& Bui, T. M. (2015). Comparision the influence between urea and ammonium sulfate to growth, yield, chlorophyll and oil content of lemongrass (Cymbopogon citratus) under drought condition. The Second National Conference on Crop Sciences (11201123). Ha Noi, Vietnam: Vietnam Academy of Agricultural Sciences.

Rao, B. R. R., Chand, S., Bhattacharya, A. K., Kaul, P. N., Singh, C. P., \& Singh. K. (1998). Response of lemongrass (Cymbopogon flexuosus) cultivars to spacings and NPK fertilizers under irrigated and rainfed conditions in semi-arid tropics. Journal of Medicinal and Aromatic Plant Sciences 20, 407-412.

Rao, E. V. S. P., Singh, M., \& Rao, R. S. G. (1985). Effect of plant spacing and application of nitrogen fertilizer on herb and essential oil yields of palmarosa (Cymbopogon martini Stapf. var. motia). The Journal of Agricultural Science 104(01), 67-70.
Singh, A., Rahman, L., Verma, R. S., Verma, R. K., Singh, U. B., Singh, S. K., Chauhan, A., \& Kukreja. A. K. (2009). Effect of plant geometry on growth and yield of lemongrass (Cymbopogon flexuosus Nees ex Steud.) cultivars from Uttarakhand Hills. Journal of Medicinal and Aromatic Plant Sciences 31, 10-12.

Singh, K., Singh, V. P., \& Singh, D. V., (1998). Effect of nitrogen and weed control on growth and yield of Java citronella (Cymbopogon winterianus Jawitt). Journal of Spices and Aromatic Crops 7(2), 95-101.

Singh, M. (2001). Long-term studies on yield, quality and soil fertility of lemongrass (Cymbopogon flexuosus) in relation to nitrogen application. The Journal of Horticultural Science and Biotechnology 76, 180-182.

Singh, M., \& Sharma. S. (2001). Influence of irrigation and nitrogen on herbage and oil yield of palmarosa (Cymbopogon martinii) under semi-arid tropical conditions. European Journal of Agronomy 14, 157-159.

Singh, M., Rao, R. S. G., \& Ramesh. S. (1997). Irrigation and nitrogen requirement of lemongrass [Cymbopogon flexuosus (Steud) Wats] on a red sandy loam soil under semiarid tropical conditions. Journal of Essential Oil Research 9, 569-574.

Singh, M., Shivaraj, B., \& Sridhara, S. (1996). Effect of plant spacing and nitrogen levels on growth, herb and oil yields of lemongrass (Cymbopogon flexuosus (Steud.) Wats. var. Cauvery). Journal of Agronomy and Crop Science 177, 101-105.

VMMU (Vietnam Military Medical University). (2013). The research news: Lemon grass. Retrieved February 03, 2017, from http://hocvienquany.edu.vn/caysa.

Wany A., Jha. S., Nigam, V. K., \& Pandey, D. M. (2013). Review article: Chemical analysis and therapeutic uses of citronella oil from Cymbopogon winterianus: A short review. International Journal of Advanced Research $1(6), 504-521$.

Weiss, E. A. (1997). Lemongrass. In Weiss, E. A. (Ed.) Essential oil crops (86-103.). Wallingford, England: CAB International.

Zheljazkov, V. D., Cantrell, C. L., Astatkie, T., \& Cannon, J. B. (2011). Lemongrass Productivity, Oil Content, and Composition as a Function of Nitrogen, Sulfur, and Harvest Time. Agronomy Journal 103(3), 805812 . 